\title{
DESAIN DAERAH KHUSUS/ ISTIMEWA DALAM SISTEM NEGARA KESATUAN REPUBLIK INDONESIA MENURUT KONSTITUSI
}

\author{
Baharudin \\ Fakultas Hukum Universitas Bandar Lampung \\ Jalan Z.A Pagar Alam No.26, Bandar Lampung \\ Email:Baharudin128@gmail.com
}

\begin{abstract}
This study aimed to analyze the regional settings specialized / special in the Unitary State of the Republic of Indonesia according to the Constitution, and examines the ideal design special areas / special in order to strengthen the system of the Republic of Indonesia according to the Constitution. Search result shows the design of a special area / special given to provincial-level areas and countylevel regions / cities. Design Award specificity status / privilege in the State of Indonesia is based on a variety of reasons, ranging from history to the strategic position of the state. Theoretically the establishment of special autonomy is one way or the choices made by a country to preserve its unity (oneness State).
\end{abstract}

Keywords: Special District; Indonesia; Constitution.

\begin{abstract}
Abstrak
Penelitian ini bertujuan untuk menganalisis mengenai pengaturan daerah khusus/istimewa dalam sistem Negara Kesatuan Republik Indonesia menurut Konstitusi, dan mengkaji desain ideal daerah khusus/istimewa dalam rangka memperkokoh sistem Negara Kesatuan Republik Indonesia menurut Konstitusi. Hasil penelusuran menunjukkan desain daerah khusus/istimewa diberikan bagi daerah setingkat provinsi dan daerah setingkat kabupaten/kota. Desain pemberian status kekhususan/keistimewaan dalam Negara Indonesia dilandasi berbagai alasan, mulai dari sejarah sampai dengan posisi strategis kenegaraan. Secara teoritis pembentukan otonomi khusus merupakan salah satu cara atau pilihan yang dilakukan oleh suatu negara untuk menjaga keutuhannya (Negarakesatuan).
\end{abstract}

Kata Kunci: Daerah Khusus/Istimewa; Indonesia; Konstitusi.

\section{A. Pendahuluan}

Otonomi daerah bukan hanya sekedar pemencaran penyelenggaraan pemerintahan untuk mencapai efesiensi dan efektifitas pemerintahan atau bukan hanya sekedar menampung kenyataan negara yang luas, penduduk banyak, dan berpulau-pulau. Otonomi pada dasarnya sebuah tatanan ketatanegaraan (staatsrechttelijk) yang berkaitan dengan dasar-dasar negara dan susunan organisasi negara, bukan hanya sekedar tatanan administrasi negara. ${ }^{1}$ Otonomi daerah juga merupakan dasar memperluas pelaksanaan demokrasi dan instrumen mewujudkan kesejahteraan umum, tidak kalah penting otonomi daerah merupakan cara memelihara negara kesatuan. Daerahdaerah otonom bebas dan mandiri mengatur dan mengurus rumah tangganya sendiri, merasa diberi tempat yang layak dalam kehidupan berbangsa dan bernegara, sehingga tidak ada alasan untuk keluar dari NKRI. ${ }^{2}$ Dengan pemberian otonomi kepada daerah, maka azas penyelenggaraan pemerintah daerah akan selalu menampilkan dua pertimbangan utama, yakni pertimbangan

\footnotetext{
1. Bagir Manan, 2005, Menyongsong Fajar Otonomi Daerah, Yogyakarta, Pusat Studi Hukum Fakultas Hukum

2. Universitas Islam Indonesia, hlm 3.

2. Ibid., hlm.25.
} 
yang berkenaan upaya menjamin kesinambungan dan keberhasilan pembangunan nasional dan pertimbangan untuk mewadahi aspirasi masyarakat di daerah, agar mereka dapat lebih diberdayakan terutama untuk menunjang pembangunan daerah. $^{3}$

UUD 1945 mengatur penyelenggaraan pemerintahan daerah pasca reformasi yang menunjukan kejelasan arah dengan dicanangkannya desentralisasi dengan otonomi seluas-luasnya, daerah memiliki kewenangan yang luas untuk mengatur dan mengelola rumah tangga daerahnya sendiri dengan prakarsa sendiri. Demi mewujudkan keadilan bagi daerah, selain adanya penyelenggaraan kewenangan otonomi seluas-luasnya, juga adanya pengakuan dan penghormatan negara terhadap satuan pemerintahan yang bersifat khusus dan istimewa. Pasal 18B Undang-undang Dasar 1945 mengatur bahwa "Negara mengakui dan menghormati satuan-satuan pemerintahan daerah yang bersifat khusus atau bersifat istimewa yang diatur dengan undangundang".

Pengakuan terhadap daerah-daerah khusus dan istimewa membawa implikasi bahwa adanya daerah-daerah yang bersifat khusus dan istimewa dalam hal tertentu dibandingkan dengan daerah lainnya, kekhususan dan keistimewaan daerah tertentu yang berdasarkan sejarah dan hak asal-usul menurut Undang-Undang Dasar Negara Republik Indonesia Tahun 1945 untuk mengatur dan mengurus kewenangan khusus dan istimewa, misalnya Papua, Aceh, DIY.

Daerah khusus/istimewa dalam desain sistem Negara Kesatuan bukan tidak menyebabkan masalah, terdapat beberapa problem, yaitu: Pertama, UUD 1945 tidak dijelaskan secara rinci dan detail mengenai desain daerah khusus/istimewa dalam hal ini apakah hanya daerah setingkat Provinsi saja yang memperoleh status khusus/istimewa. Kedua, tidak dijelaskan kriteria daerah Provinsi, Kabupaten dan Kota yang dapat dijadikan daerah khusus/ istimewa, problem ini masih menjadi pilihan politik pemerintah. Ketiga, dalam perspektif negara kesatuan, maka ketidakjelasan aturan dan kriteria pemberian status daerah khusus/ istimewa bagi daerah tertentu dapat menyebabkan adanya kecemburuan bagi daerah lain yang merasa memiliki sifat kekhususuan dan keistimewaan.

Oleh karena itu, yang harus dipikirkan lebih lanjut untuk mengatasi problem tersebut adanya membuat desain yang ideal dalam menata daerah-daerah khusus/istimewa dalam kerangka memperkokoh desain negara kesatuan yang telah disepakati bersama. Maka, penting untuk melakukan kajian yang berfokus pada permasalahan bagaimana pengaturan daerah khusus/istimewa dalam sistem Negara Kesatuan Republik Indonesia menurut Konstitusi; dan, bagaimana desain ideal daerah khusus/istimewa dalam rangka memperkokoh sistem Negara Kesatuan Republik Indonesia menurut Konstitusi?

\section{B. Pembahasan}

\section{Pengaturan Daerah Istimewa/ Khusus di Indonesia.}

Berdasarkan kajian mendalam yang penulis lakukan terhadap berbagai peraturan perundang-undangan yang sedang berlaku, terdapat beberapa daerah yang sampai saat ini masih memiliki status keistimewaan atau kekhususan. Status keistimewaan dan kekhususan tersebut hanya dimiliki oleh daerah ditingkat provinsi termasuk kabupaten, adapun daerah-daerah yang memiliki status sebagai daerah istimewa atau daerah khusus, meliputi:

a. Provinsi Daerah Khusus Ibukota Jakarta

Pemerintahan Daerah Provinsi Daerah Khusus Ibukota Jakarta adalah penyelenggaraan urusan pemerintahan oleh pemerintah daerah dan Dewan Perwakilan Rakyat Daerah Provinsi Daerah Khusus Ibukota Jakarta menurut asas otonomi dan tugas pembantuan dengan prinsip otonomi seluas-luasnya dalam sistem dan prinsip Negara Kesatuan Republik Indonesia. Provinsi Daerah Khusus Ibukota Jakarta adalah provinsi yang mempunyai kekhususan dalam penyelenggaraan pemerintahan daerah karena kedudukannya sebagai Ibukota Negara Kesatuan Republik Indonesia. Dasar

3. Hernan Tori, "Kebijakan Otonomi Daerah Dan Keadilan Dalam Mewujudkan Good Governance”, Jurnal TAPIs, Vol.7, No.12, Juni 2011, hlm. 98. 
pemikiran yang melatarbelakangi pemberian status kekhususan bagi Provinsi DKI Jakarta adalah:

1) Provinsi DKI Jakarta sebagai satuan pemerintahan yang bersifat khusus dalam kedudukannya sebagai Ibukota Negara. Oleh karena itu, perlu diberikan kekhususan tugas, hak, kewajiban, dan tanggung jawab dalam penyelenggaraan pemerintahan daerah.

2) Provinsi DKI Jakarta berhadapan dengan karakteristik permasalahan yang sangat kompleks dan berbeda dengan provinsi lain, sehingga memerlukan pemecahan masalah secara sinergis melalui berbagai instrumen.

Adapun beberapa hal yang terkait dengan kekhususan Daerah Khusus Ibukota Jakarta, meliputi:

1) Kewenangan Pemerintah Provinsi DKI Jakarta sebagai Ibukota Negara Kesatuan Republik Indonesia yang meliputi penetapan dan pelaksanaan kebijakan dalam beberapa bidang.

2) Pemerintah Provinsi DKI Jakarta dipimpin oleh satu orang Gubernur dibantu oleh satu orang Wakil Gubernur yang dipilih secara langsung melalui pemilihan umum.

3) Gubernur dalam kedudukannya sebagai wakil Pemerintah dan Kepala Daerah Provinsi DKI Jakarta yang diberikan kekhususan tugas, hak, kewajiban, dan tanggung jawab dalam kedudukan DKI Jakarta sebagai Ibukota Negara Kesatuan Republik Indonesia.

4) Gubernur mempunyai hak protokoler, termasuk mendampingi Presiden dalam acara kenegaraan sesuai dengan ketentuan peraturan perundangundangan.

5) Walikota/ bupati diangkat, bertanggungjawab dan diberhentikan oleh Gubernur atas pertimbangan DPRD Provinsi DKI Jakarta dari Pegawai Negeri Sipil yang memenuhi persyaratan.

6) Pemerintah DKI Jakarta dapat mengusulkan kepada Pemerintah terkait dengan penambahan jumlah dinas, lembaga teknis provinsi serta dinas, dan/atau lembaga teknis daerah baru sesuai dengan kebutuhan dan kemampuan anggaran keuangan daerah.

7) Pendanaan Pemerintah Provinsi DKI Jakarta dalam menyelenggarakan urusan pemerintahan yang bersifat khusus dalam kedudukannya sebagai Ibukota Negara Kesatuan Republik Indonesia dalam APBN.

8) Pemerintah Provinsi DKI Jakarta dapat mengusulkan pembentukan kawasan khusus di wilayahnya kepada Pemerintah, kawasan khusus dibentuk untuk menyelenggarakan fungsi-fungsi pemerintahan tertentu yang bersifat khusus dan untuk kepentingan nasional/berskala nasional.

b. Provinsi Daerah Istimewa Yogyakarta

Daerah Istimewa Yogyakarta merupakan daerah provinsi yang mempunyai keistimewaan dalam penyelenggaraan urusan pemerintahan dalam kerangka NKRI. Keistimewaan adalah keistimewaan kedudukan hukum yang dimiliki oleh DIY berdasarkan sejarah dan hak asal-usul menurut Undang-Undang Dasar Negara Republik Indonesia Tahun 1945 untuk mengatur dan mengurus kewenangan istimewa. Dasar pemikiran yang melatarbelakangi pemberian status keistimewaan bagi Provinsi Daerah Istimewa Yogyakarta adalah:

1) Status istimewa yang melekat pada DIY merupakan bagian integral dalam sejarah pendirian negara-bangsa Indonesia.

2) Masyarakat Yogyakarta yang homogen pada awal kemerdekaan meleburkan diri ke dalam masyarakat Indonesia yang majemuk, baik etnik, agama maupun adat istiadat.

3) Setelah Proklamasi 17 Agustus 1945, Sultan Hamengku Buwono IX dan Adipati Paku Alam VIII memutuskan untuk menjadi bagian dari Indonesia.

4) Peran Yogyakarta terus berlanjut di era revolusi kemerdekaan yang diwujudkan melalui upaya Kasultanan dan Kadipaten serta rakyat Yogyakarta dalam mempertahankan, mengisi, dan menjaga keutuhan Negara Kesatuan Republik Indonesia.

5) Kasultanan dan Kadipaten tetap diposisikan sebagai simbol pengayom 
kehidupan masyarakat dan tetap sebagai ciri keistimewaan DIY.

6) Pengaturan Keistimewaan DIY bertujuan untuk mewujudkan tata pemerintahan yang baik dan demokratis, ketenteraman dan kesejahteraan masyarakat, menjamin ke-bhinnekatunggal-ika-an, dan melembagakan peran dan tanggung jawab Kasultanan dan Kadipaten dalam menjaga dan mengembangkan budaya Yogyakarta yang merupakan warisan budaya bangsa.

Berdasar Pasal 6 Undang-undang Nomor 13 Tahun 2012 menyebutkan bahwa "Kewenangan Istimewa DIY berada di Provinsi", kewenangan Istimewa ini merupakan wewenang tambahan tertentu yang dimiliki DIY selain wewenang sebagaimana ditentukan dalam Undangundang Nomor 32 tentang Pemerintahan Daerah. Kewenangan dalam urusan Keistimewaan harus mendasarkan pada nilainilai kearifan lokal dan keberpihakan kepada rakyat, kewenangan Istimewa terkait dengan kewenangan tata cara pengisian jabatan, kedudukan, tugas, dan wewenang Gubernur dan Wakil Gubernur.

c. Provinsi Nangroe Aceh Darussalam

Aceh adalah daerah provinsi yang merupakan kesatuan masyarakat hukum yang bersifat istimewa dan diberi kewenangan khusus untuk mengatur dan mengurus sendiri urusan pemerintahan dan kepentingan masyarakat setempat sesuai dengan peraturan perundang-undangan dalam sistem dan prinsip NKRI berdasarkan UUD 1945. Pemerintahan Aceh adalah pemerintahan daerah provinsi dalam sistem Negara Kesatuan Republik Indonesia berdasarkan Undang-Undang Dasar Negara Republik Indonesia Tahun 1945 y ang menyelenggarakan urusan pemerintahan yang dilaksanakan oleh Pemerintah Daerah Aceh dan Dewan Perwakilan Rakyat Daerah Aceh sesuai dengan fungsi dan kewenangan masing-masing. Dasar pemikiran yang melatarbelakangi pemberian status keistimewaan bagi Provinsi Aceh sebagaimana tertuang dalam Penjelasan Undang-undang Pemerintahan Aceh:

1) Perjalanan ketatanegaraan Republik Indonesia menempatkan Aceh sebagai satuan pemerintahan daerah yang bersifat istimewa dan khusus, terkait dengan karakter khas sejarah perjuangan masyarakat Aceh yang memiliki ketahanan dan daya juang tinggi.

2) Ketahanan dan daya juang tinggi tersebut bersumber dari pandangan hidup yang berlandaskan Syari'at Islam yang melahirkan budaya Islam yang kuat, sehingga Aceh menjadi salah satu daerah modal bagi perjuangan dalam merebut dan mempertahankan kemerdekaan NKRI

3) Aspirasi yang dinamis masyarakat Aceh bukan saja dalam kehidupan adat, budaya, sosial, dan politik mengadopsi keistimewaan Aceh, melainkan juga memberikan jaminan kepastian hukum dalam segala urusan karena dasar kehidupan masyarakat Aceh yang religius telah membentuk sikap, daya juang yang tinggi, dan budaya Islam yang kuat.

4) Bencana alam, gempa bumi, dan tsunami yang terjadi di Aceh telah menumbuhkan solidaritas seluruh potensi bangsa untuk membangun kembali masyarakat dan wilayah Aceh. Begitu pula telah tumbuh kesadaran yang kuat dari Pemerintah dan Gerakan Aceh Merdeka untuk menyelesaikan konflik secara damai, menyeluruh, berkelanjutan, serta bermartabat yang permanen dalam kerangka Negara Kesatuan Republik Indonesia. Hal demikian adalah sebuah kemutlakan.

Beberapa hal yang berkaitan dengan pelaksanaan kekhususan Provinsi Nanggroe Aceh Darussalam, yaitu:

1) Asas Penyelenggaraan Pemerintahan yaitu asas ke-Islaman.

2) Pasal 125 UU Pemerintahan Aceh mengatur ketentuan bahwa Pemerintahan Aceh dan Pemerintahan Kabupaten/Kota bertanggung jawab atas penyelenggaraan pelaksanaan syari'at Islam, sekaligus menjamin kebebasan, membina kerukunan, menghormati nilai-nilai agama yang dianut oleh umat beragama dan melindungi sesama umat beragama untuk menjalankan ibadah sesuai 
dengan agama yang dianutnya.

3) Pasal 16 UU Pemerintahan Aceh menentukan kewenangan Pemerintahan Aceh yang merupakan urusan dalam skala Aceh yang bersifat khusus yang meliputi: (a) penyelenggaraan kehidupan beragama dalam bentuk pelaksanaan syari'at Islam bagi pemeluknya di Aceh dengan tetap menjaga kerukunan hidup antar umat beragama; (b) penyelenggaraan kehidupan adat yang bersendikan agama Islam; (c) penyelenggaraan pendidikan yang berkualitas serta menambah materi muatan lokal sesuai dengan syari'at Islam; (d) peran ulama dalam penetapan kebijakan Aceh; dan; (e ) penyelenggaraan dan pengelolaan ibadah haji sesuai dengan peraturan perundang-undangan.

4) Dewan Perwakilan Rakyat Daerah Aceh (DPRA) adalah unsur penyelenggara Pemerintahan Daerah Aceh yang anggotanya dipilih melalui pemilihan umum. Dewan Perwakilan Rakyat Daerah Kabupaten/ Kota (DPRK) adalah unsur penyelenggara pemerintahan daerah kabupaten/kota yang anggotanya dipilih melalui pemilihan umum.

5) Mahkamah Syar'iyah Aceh dan Mahkamah Syar'iyah Kabupaten/Kota adalah pengadilan selaku pelaksana kekuasaan kehakiman dalam lingkungan peradilan agama yang merupakan bagian dari sistem peradilan nasional. Peradilan syari'at Islam di Aceh adalah bagian dari sistem peradilan nasional dalam lingkungan peradilan agama yang dilakukan oleh Mahkamah Syar'iyah yang bebas dari pengaruh pihak mana pun.

6) Majelis Permusyawaratan Ulama (MPU) adalah majelis yang anggotanya terdiri atas ulama dan cendekiawan muslim yang merupakan mitra kerja Pemerintah Aceh dan DPRA.

7) Lembaga Wali Nanggroe merupakan kepemimpinan adat sebagai pemersatu masyarakat yang independen, berwibawa, dan berwenang membina dan mengawasi penyelenggaraan kehidupan lembaga-lembaga adat, adat istiadat, dan pemberian gelar/derajat dan upacara-upacara adat lainnya.

8) Lembaga adat berfungsi dan berperan sebagai wahana partisipasi masyarakat dalam penyelenggaraan Pemerintahan Aceh dan pemerintahan kabupaten/kota di bidang keamanan, ketenteraman, kerukunan, dan ketertiban masyarakat.

9) Partai Politik Lokal.

10) Dalam Pemerintahan Aceh dibentuklah Qanun, baik di tingkat Provinsi Aceh maupun Kabupaten/Kota.

d. Otonomi Khusus Papua

D a s a p e m i k i r a y a $\mathrm{g}$ melatarbelakangi pemberian status otonomi khusus bagi Provinsi Papua, yaitu:

1) Integrasi bangsa dalam wadah NKRI harus tetap dipertahankan dengan menghargai kesetaraan dan keragaman kehidupan sosial budaya masyarakat Papua.

2) Dalam kenyataan berbagai kebijakan dalam penyelenggaraan pemerintahan dan pembangunan yang sentralistik belum sepenuhnya memenuhi rasa keadilan, belum sepenuhnya memungkinkan tercapainya kesejahteraan rakyat, belum sepenuhnya mendukung terwujudnya penegakan hukum, dan belum s e penuhnya menampakkan penghormatan terhadap Hak Asasi Manusia(HAM) di Provinsi Papua.

3) Pengelolaan dan pemanfaatan hasil kekayaan alam Provinsi Papua belum digunakan secara optimal untuk meningkatkan taraf hidup masyarakat asli, sehingga telah mengakibatkan terjadinya kesenjangan antara Provinsi Papua dan daerah lain, serta merupakan pengabaian hak-hak dasar penduduk asli Papua.

4) Dalam rangka mengurangi kesenjangan antara Provinsi Papua dan Provinsi lain, dan meningkatkan taraf hidup masyarakat di Provinsi Papua, serta memberikan kesempatan kepada penduduk asli Papua

5) Adanya momentum reformasi di Indonesia memberi peluang bagi timbulnya pemikiran dan kesadaran baru untuk menyelesaikan berbagai permasalahan besar bangsa Indonesia 
dalam menata kehidupan berbangsa dan bernegara yang lebih baik.

Beberapa hal penting terkait dengan kedudukan kelembagaan dan peranan kelembagaan yang menjadi kekhususan Provinsi Papua, yaitu:

1) Gubernur. Salah satu syarat untuk dapat dipilih menjadi Gubernur dan Wakil Gubernur adalah Warga Negara Republik Indonesia adalah orang asli Papua.

2) Penyebutan secara khusus Dewan Perwakilan Rakyat Papua merupakan Dewan DPRD Provinsi Papua sebagai badan legislatif Daerah Provinsi Papua.

3) Dalam rangka penyelenggaraan Otonomi Khusus di Provinsi Papua dibentuk Majelis Rakyat Papua yang merupakan representasi kultural orang asli Papua yang memiliki kewenangan tertentu dalam rangka perlindungan hak-hak orang asli Papua, dengan berlandaskan pada penghormatan terhadap adat dan budaya, pemberdayaan perempuan, dan pemantapan kerukunan hidup beragama.

4) Kekuasaan kehakiman di Provinsi Papua dilaksanakan oleh Badan Peradilan sesuai dengan peraturan perundang-undangan, namun disamping kekuasaan kehakiman tersebut juga diakui adanya peradilan adat di dalam masyarakat hukum adat tertentu. Peradilan adat adalah peradilan perdamaian di lingkungan masyarakat hukum adat, yang mempunyai kewenangan memeriksa dan mengadili sengketa perdata adat dan perkara pidana di antara para warga masyarakat hukum adat yang bersangkutan.

5) Pemerintah Provinsi Papua wajib mengakui, menghormati, melindungi, memberdayakan dan mengembangkan hak-hak masyarakat adat dengan berpedoman pada ketentuan peraturan hukum yang berlaku, yang meliputi hak ulayat masyarakat hukum adat dan hak perorangan para warga masyarakat hukum adat yang bersangkutan.
6) Otonomi Khusus bagi Provinsi Papua pada dasarnya adalah pemberian kewenangan yang lebih luas bagi Provinsi dan rakyat Papua untuk mengatur dan mengurus diri sendiri di dalam kerangka NKRI. Kewenangan yang lebih luas berarti pula tanggung jawab yang lebih besar bagi Provinsi $\mathrm{d} a \mathrm{n}$ rakyat $\mathrm{Papua} u n t \mathrm{k}$ menyelenggarakan pemerintahan dan mengatur pemanfaatan kekayaan alam di Provinsi Papua untuk sebesarbesarnya bagi kemakmuran rakyat Papua sebagai bagian dari rakyat Indonesia sesuai dengan peraturan perundang-undangan.

\section{Desain Ideal dan Implikasi Daerah Istimewa/Khusus di Indonesia.}

Thomas Paine sebagaimana dikutip oleh Johannes Suhardjana menyebutkan bahwa Konstitusi adalah superior dan mempunyai wewenang untuk mengikat karena memang dimaksudkan untuk mengatur kekuasaan sehingga akan berjalan sesuai dengan apa yang dikehendaki oleh rakyat. Undang-undang Dasar 1945 mengatur daerah khusus/istimewa yang didasarkan pada ketentuan Pasal 18A ayat (1) dan dan Pasal 18B ayat (1) dan ayat (2). Pasal 18A ayat (1) UUD 1945 mengatur bahwa Hubungan wewenang antara pemerintah pusat dan pemerintah daerah provinsi, kabupaten, dan kota atau antara provinsi dan kabupaten dan kota, diatur dengan Undang-undang dengan memperhatikan kekhususan dan keragaman daerah. Sedangkan menurut Pasal 18B Ayat (1) UUD NRI 1945 Negara mengakui dan menghormati satuan-satuan pemerintahan daerah yang bersifat khusus atau bersifat istimewa yang diatur dengan undang-undang.

Menurut Jimly Asshiddiqie bahwa yang dimaksud sebagai satuan pemerintah daerah adalah satuan pemerintah daerah provinsi, satuan pemerintah daerah kabupaten/kota, atau pemerintah desa yang bersifat khusus dan istimewa. ${ }^{5}$ Adanya prinsip mengakui dan menghormati pemerintahan daerah yang bersifat khusus dan istimewa, ketentuan ini mendukung keberadaan berbagai satuan

4. Johannes Suhardjana, "Supremasi Konstitusi adalah Tujuan Negara”, Jurnal Dinamika Hukum, Vol. 10, No. 3, September 2010, hlm.257.

5. Jimly Asshiddiqie, 2002, Konsolidasi Naskah UUD 1945 Setelah Perubahan Keempat, Jakarta, Pusat Studi HTN FH UI, hilm.24 
pemerintahan bersifat khusus atau istimewa (baik di tingkat provinsi, kabupaten dan kota, atau desa). ${ }^{6}$

Artinya dalam konteks desain ideal daerah khusus atau istimewa menunjukan bahwa Pemerintah dapat saja Pemerintah Pusat memberikan status daerah khusus/daerah istimewa bagi Provinsi, Kabupaten/ Kota yang dinilai memenuhi syarat sebagai daerah khusus/istimewa. Pemahaman daerah khusus dan istimewa itu menunjukan adanya perbedaan makna, syarat, dan latar belakang yang menjadi alasan suatu daerah diberikan status khusus dan status istimewa, karena dasar dan pemaknaan (pengertian) daerah khusus dan istimewa itu berbeda.

Terkait dengan desain ideal pemberian status kekhususan atau keistimewaan bagi daerah di Indonesia, maka penulis berpendapat bahwa desain ideal bagi daerah tersebut adalah ditingkat provinsi maupun ditingkat kabupaten dan kota, dalam arti daerah khusus akan dibentuk berdasarkan adanya alasan riil terkait dengan keadaan daerah, sementara status keistimewaan lebih menekankan pada aspek sejarah (asal-usul suatu daerah). Dalam praktik ketatanegaraan Indonesia, Indonesia pernah memberikan status khusus dan istimewa terhadap provinsi maupun Kabupaten, ditingkat provinsi yang sampai sekarang masih berlaku adalah Provinsi Daerah Khusus Ibukota Jakarta, Provinsi Daerah Istimewa Yogyakarta, Provinsi Nangroe Aceh Darussalam, dan Provinsi Papua (point-point kekhususan dan/ atau keistimewaan telah diuraian pada pembahasan di atas).

Pembentukan daerah khusus/istimewa di Indonesia, dalam arti bahwa pemberian status kekhususan/keistimewaan bagi provinsi di Indonesia juga memiliki dua implikasi, yaitu: (1) adanya keinginan daerah lain untuk kembali menuntut daerah istimewa dan adanya keinginan daerah lain untuk membentuk daerah baru yang memiliki kewenangan khusus atau keistimewa; (2) implikasi bagi penguatan negara kesatuan.

\section{Simpulan}

Berdasarkan hasil penelitian di atas, dapat disimpulkan beberapa hal-hal yang menjadi pokok pengkajian, yaitu: (1) desain daerah khusus/ istimewa tidak hanya diberikan kepada daerah setingkat provinsi, tetapi daerah setingkat kabupaten/ kota. Daerah setingkat provinsi yang masih memiliki status kekhususan / keistimewaan meliputi: DKI Jakarta, Provinsi Nangroe Aceh Darussalam (NAD), Provinsi Papua, dan Provinsi Daerah Istimewa Yogyakarta. Sementara daerah kabupaten yang masih memiliki status kekhususan adalah kabupaten/ kota yang menjadi bagian pemerintahan Aceh. (2) Desain pemberian status kekhususan / keistimewaan dalam negara Indonesia dilandasi berbagai alasan, yaitu: Provinsi DKI Jakarta sebagai satuan pemerintahan yang bersifat khusus dalam kedudukannya sebagai Ibukota NKRI, adanya ketahanan dan daya juang tinggi tersebut bersumber dari pandangan hidup yang berlandaskan syari'at Islam yang melahirkan budaya Islam yang kuat, hak asalusul, dan lainnya. (3) Secara teoritis bahwa pembentukan otonomi khusus merupakan salah satu cara atau pilihan yang di lakukan oleh suatu negara untuk menjaga keutuhannya. Dalam beberapa kasus di Indonesia pilihan pemberian otonomi khusus dilakukan sebagai jalan tengah agar suatu daerah tidak melepaskan diri dari NKRI sebagaimana terjadi di Propinsi Nanggroe Aceh Darussalam (NAD) dan Papua, selain itu juga mengembalikan hak-hak daerah yang memiliki asal-usul yang bersifat istimewa, seperti Daerah Istimewa Yogyakarta.

\section{Daftar Pustaka}

Asshiddiqie Jimly, 2002, Konsolidasi Naskah UUD 1945 Setelah Perubahan Keempat, Jakarta, Pusat Studi HTN FH UI.

Fajar Mukti dan Yulianto Achmad, 2006, Dualisme Penelitian Hukum Normatif dan Empiris, Yogyakarta, Pustaka Pelajar.

6. Ni'matul Huda, "Berkayuh Diantara Bentuk Negara Kesatuan Dan Federal”, tersedia di website http://pshk. law.uii.ac.id/index.php?option=com_content\&task=view\&id=39\&Itemid=126, diakses pada tanggal 17 Oktober 2013. 
Huda Ni'matul, "Berkayuh Diantara Bentuk Negara Kesatuan Dan Federal", tersedia di website, diakses pada tanggal 17 Oktober 2013.

Manan Bagir, 2005, Menyongsong Fajar Otonomi Daerah, Yogyakarta, Pusat Studi Hukum Fakultas Hukum Universitas Islam Indonesia.

Suhardjana Johannes, "Supremasi Konstitusi adalah Tujuan Negara", Jurnal Dinamika Hukum, Vol. 10, No. 3, September 2010

Tori Hernan, "Kebijakan Otonomi Daerah Dan Keadilan Dalam Mewujudkan Good Governance", Jurnal TAPIs, Vol.7, No.12, Juni 2011

Undang-Undang Dasar 1945

Undang-Undang No.32 Tahun 2004 tentang Pemerintahan Daerah

Undang-Undang No.21 Tahun 2001 tentang Otonomi Khusus Bagi Provinsi Papua

Undang-undang No.11 Tahun 2011 tentang Pemerintahan Aceh

Undang-Undang No.29 Tahun 2007 tenntang Pemerintahan Provinsi Daerah Khusus Ibukota Jakarta Sebagai Ibukota Negara Kesatuan Republik Indonesia

Undang-Undang No.13 Tahun 2012 tentang Keistimewaan Daerah Istimewa Yogyakarta 